\title{
KUALITAS PELAYANAN TERHADAP KEPUASAN NASABAH PT. JASA RAHARJA MEDAN
}

\author{
Reza Nurul Ichsan ${ }^{1)}$, Ahmad Karim²), \\ Universitas Pembinaan Masyarakat Indonesia ${ }^{1,2)}$ \\ rezaichsan31@gmail.com \\ ahmadkarimk@yahoo.co.id
}

\begin{abstract}
Abstrak
Permasalah dalam penelitian ini adalah;Bagaimana pengaruh kualitas pelayanan terhadap kepuasan nasabah PT. Jasa Raharja; Metode analisis data dalam penelitian ini yaitu metode deskriptif dan metode kuantitatif. Dalam hal ini penulis menggunakan analisis statistik regresi linear sederhana yang menghasilkan output uji $t$. Pengolahan data dilakukan dengan menggunakan bantuan program SPSS 20.00 for Windows. Hasil penelitian ini menunjukkan Nilai regresi yang diporela adalah $Y=$ $6.775+0,681 X$, diartikan bahwa kepuasan nasabah akan bernilai 6,775 saat kualitas pelayanan nilainya adalah 0 dan 0,681 menyatakan bahwa kenaikan satu satuan kualitas pelayanan akan meningkatkan kepuasan nasabah 0,681 dan nilait hitung >9.295t tabel>1.996, maka Ha diterima dan Ho ditolak. Jadi dapat disimpulkan bahwa kualitas pelayanan berpengaruh signifikan terhadap kepuasan nasabah. Berdasarkan Uji koefisien determinasi diperoleh $R$ diperoleh besarnya pengaruh kualitas pelayanan terhadap kepuasan nasabah sebesar 0,542 atau sebesar 5,42\%.
\end{abstract}

Kata kunci : kualitas pelayanan, kepuasan nasabah

\begin{abstract}
The problem in this research is "How can determined service quality faced customer satisfaction PT.JasaRaharja". Method of dat analysis in this research that is descriptive and quantitative methods. In this case case the outhor uses simple linear regression statistical analysis that generates output $t$ test. Data processing was performed using SPSS for windows 20.00. The result of this study to show values obtained regression is $Y=6.775+0,681 X$, it's meansatisfaction customer will be valued at 6.775 when the quality of service value is 0 and 0.681 states that an increase of the one unit service quality will increase customer satisfaction by 0,681\% and tcount $>t_{\text {tabel }}(9.295>1.966)$, then Ha accepted and Ho rejected. The conclution that service quality have a significant effect to customer satisfaction. According to the table $R$ Obtained by the determined of service quality faced customer satisfaction is bout 0,542 for $54.2 \%$.
\end{abstract}

Keywords : service quality, customer satisfaction

\section{PENDAHULUAN}

Dimasa sekarang tuntutan terhadap penyelenggaraan pelayanan dewasa ini semakin ketat meningkat.Hal ini dapat dilihat adanya peningkatan layanan masyarakat yang dilakukan oleh instansi pemerintah maupun perusahaan swasta yang bergerak dibidang jasa pelayanan.Pelayanan adalah aktivitas atau kegiatan yang ditawarkan oleh irganisasi atau perorangan kepada pelanggan atau nasabah, yang bersifat tidak berwujud dan tidak dapat dimiliki.Pelayanan merupakan bagian dari beberapa rangkaian aktivitas yang diperuntukkan kepada orang yang membutuhkan layanan.

Menurut Keputusan Menteri Pendayagunaan Aparatur Negara Nomor 81 Tahun 1993, "pelayanan adalah suatu bentuk kegiatan pelayanan yang dilaksanakan oleh instansi pemerintah pemerintah baik dipusat maupun di daerah, Badan Usaha Milik Negara (BUMN) dan Badan Usaha Milik Daerah (BUMD)dalam bentuk barang dan jasa dalam rangka pemenuhan kebutuha masyarakat sesuai dengan peraturan perundang-undangan. "Pelayanan yang baik adalah pelayanan 
yang mampu memberikan kepuasan bagi yang menerima pelayanan sesuai dengan kualitas standarisasi yang telah ditentukan oleh lembaga atau perusahaan pengguna jasa.Standar pelayanan adalag tolak ukur yang dipergunakan sebagai pedoman penyelenggaraan pelayanan dan acuan penilaian kualitas pelayanan sebagai kewajiban dan janji penyelenggara kepada masyarakat dalam rangka pelayanan yang berkualitas, cepat, mudah, terjangkau, dan terukur.

Memang tidak mudah menjadi yang terbaik, selain harus menyediakan kualitas pelayanan terbaik juga ada faktor pola perilaku konsumen yang tidak mudah ditembak, apalagi di Indonesia yang terdiri dari berbagai macam budaya, sehingga memiliki ragam perilaku yang berbeda pula .Hal ini sesuai pernyataan bahwa salah satu faktor utama yang harus diperhatikan oleh perusahaan dalam meningkatkan kepuasan konsumen adalah kualitas pelayanan.

Pelanggan diibaratkan seorang raja yang harus dilayani, namun hal ini bukan berarti menyerahkan segala-galanya kepada pelanggan. Usaha memuaskan kebutuhan pelanggan harus dilakukan secara menguntungkan. Kepuasan pelanggan merupakan suatu hal yang sangat berharga demi mempertahankan keberadaan pelanggan.

Selain itu semakin banyak persaingan dalam jasa asuransi untuk strategi yang paling tepat guna memenangkan persaingan. Salah satu strategi untuk meraih kesuksesan dalam industry asuransi adalah dengan cara menciptakan kepuasan nasabah. Oleh karena itu, PT.Jasa Raharja Medan memproritaskan kualitas produk dengan memberikan pelayanan dan fasilitasfasilitas unggulan yang tidak dimiliki oleh pesaing yang tentunya akan berakibat pada kepuasan yang diperoleh nasabah.

Mengambil penelitian ini dirancang untuk menguji tingkat pelayanan terhadap kepuasan nasabah dan untuk mengetahui apakah kualitas pelayanan berupa wujud fisik (sangibles), kehandalan (reability), daya tanggap (responsiveness), jaminan (assurance) dan kepedulian (empaty) berpengaruh pada kepuasan nasabah. Dalam industry jasa, pelanggan pasti berharap untuk mendapat pelayanan yang baik, sementara itu dipihak lain pemberi jasa mempunyai standar kualitas dalam memberikan jasanya.

Berdasarkan latar belakang di atas, maka penulis melakukan penelitian dengan judul " Analisis Pengaruh Kualitas Pelayanan Terhadap Kepuasan Nasabah?

\section{METODE}

Penulis melakukan penelitian di PT Jasa Raharja Medan yang beralamat di Jln. Gatot Subroto Medan.Populasi pada penelitia ini adalah Seluruh Nasabah Jasa Raharja yang mempunyai STNK tahun 2017 berjumlah 47.430 orang dengan jumlah rata-rata kunjungan per hari 300 orang. Untuk menentukan sampel ini peneliti menggunakan rumus Slovin. Menurut Sugiyono (2013:49) sampel adalah bagian dari jumlah dan karakteristik yang dimiliki populasi tersebut.Adapun teknik pengambilan sampel penelitian ini menggunakan teknik proportionalrandom sampling. Alasan menggunakn ini karena yang menjadi populasi dalam penelitian ini hanya nasababah Jasa Raharja berdasarkan nomor antrian . Maka sampel 75 responden. Metode analisis regresi sederhana adalah metode statistik yang berfungsi untuk menguji sejauh mana hubungan sebab akibat antara variabel kualitas Pelayanan (X) terhadap variabel Kepuasan Pelanggan (Y).

Model Persamaan Regresi Linear Sederhana adalah sebagai berikut:

$\mathrm{Y}=\mathrm{a}+\mathrm{bX}+\mathrm{e}$

Dimana:

$\mathrm{Y}=$ Kepuasan Nasabah

$\mathrm{a}=$ Konstanta

$\mathrm{b}=$ Koefisien variabel $\mathrm{X}$

$\mathrm{X}=$ Kualitas Pelayanan

$\mathrm{e}=$ Faktor lain yang tidak termasuk dalam penelitian 


\section{HASIL DAN PEMBAHASAN}

\subsubsection{Sejarah Singkat Perusahaan}

Berdirinya Jasa Raharja tidak terlepas dari kebijakan pemerintah untuk melakukan nasionalisasi terhadap perusahaan-perusahaan milik Belanda dengan diundangkannya Undang-Undang No.86 Tahun 1958 tentang Nasionalisasi Perusahaan Belanda. Penjabaran dari Undang-Uudang tersebut dalam bidang asuransi kerugian, pemerintah melakukan nasionalisasi perusahaan-perusahaan asuransi kerugian Belanda berdasarkan Peraturan Pemerintah (PP) No.6 Tahun 1960 tentang Penentuan Perusahaan Asuransi Kerugian Belanda yang dikenakan Nasionalisasi.

\subsubsection{Uji Validitas Kualitas Pelayanan} (X)

1. Uji Validitas Variabel Kualitas Pelayanan, uji validitas menggunakan pearson product moment pada 5 item soal yang diujikan, diperoleh hasil bahwa seluruh item soal memiliki nilai $r$ $>0.227$ maka dapat diambil kesimpulan seluruh item soal valid.

2. Uji Reliabilitas Variabel Y (Kepuasan Pelanggan), berdasarkan hasil perhitungan bahwa nilai alpha lebih besar dari 0,6 yaitu sebesar 0.624. Maka alat ukur dapat dikatakan reliabel dan termasuk dalam kategori reabilitas tinggi.

\subsection{Regresi Linear Sederhana}

$\begin{array}{rrr}\text { Analisis } & \text { regresi linier sederhana } \\ \text { digunakan } & \text { untuk } & \text { menentukan }\end{array}$ ketergantungan satu variabel terikat dengan variabel bebas. Khususnya dalam penelitian ini untuk melihat Pengaruh Kualitas Pelayanan (X) terhadap Kepuasan Nasabah (Y).

Berdasarkan hasil penelitian pengolahan data dengan bantuan program SPSS 20 untuk analisa regresi sederhana diperoleh data pada diperoleh dari tabel coefficient yang dapat pada kolom B, yaitu

$$
Y=6.775+0.681 X
$$

Berdasarkan persamaan tersebut dapat diketahui bahwa :

1. Konstanta (a) $=6,775$ menunjukkan nilai konstan, jika nilai variabel bebas (kualitas pelayanan) $=0$ maka kepuasan nasabah (Y) akan sebesar 6,775

Koefisien variabel kualitas pelayanan memiliki pengaruh sebesar 0,681 terhadap variabel kepuasan nasabah (Y), artinya jika variabel kualitas pelayanan ditingkatkan sebesar satu satuan maka kepuasan nasabah akan meninglkat sebesar 0,681

Tabel 4.14 Nilai Korelasi $\mathrm{R}^{2}(\mathrm{R})$ DAN Koefisien Determinan ( Rs quare) Variabel

Koefisiendeterminasi pada intinya mengukur seberapa jauh kemampuan model dalam menerangkan variasi dari variabel dependen. Koefisien determinasi dapat diperoleh dengan cara mengkuadratkan koefisien korelasi atau $R$ Squared $\left(\mathrm{R}^{2}\right)$. Berdasarkan output diatas didapatkan nilai $\mathrm{R}^{2}$ sebesar 0.542 , sehingga dapat diambil kesimpulan bahwa Kualitas Pelayanan (X) mempengaruhi Kepuasan Nasabah (Y) sebesar 54.2\% dan sisinya $46,8 \%$ dan dipengaruhi oleh faktor-faktor yang tidak dimasukkan dalam penelitian.

\subsection{Uji Normalitas}

Uji normalitas data adalah hal yang lazim dilakukan sebelum sebuah metode statistik.Tujuan uji normalitas adalah untuk mengetahui apakah distribusi sebuah data mengikuti atau mendekati distribusi normal. Dalam penelitian ini uji normalitas yang digunakan adalah uji Normalitas Kolmogorov-Smirnov yang dihitung dengan bantuan program SPSS 20.00 . Output diatas variabel Kualitas Peayanan (X) memperoleh nilai signifikansi sebesar $0.079>0.05$, dan variabel Kepuasan Nasabah (Y) memperoleh nilai signifikansi sebesar $0.065>0.05$ sehingga dapat diambil kesimpulan bahwa seluruh data dalam penelitian ini berdistribusi normal 
Analisis pengujian individual atau parsial (Uji t) diperlukan untuk mengetahui bahwa variabel independen secara parsial mempunyai pengaruh yang signifikan terhadap variabel dependen Pengambilan keputusan dalam uji ini didasarkan pada tingkat signifikansi sebesar 5\% atau 0,05. Maka $\mathrm{H}_{\mathrm{O}}$ ditolak dan $\mathrm{H}_{\mathrm{a}}$ diterima. adalah jika :

Dasar pengambilan keputusan uji $\mathrm{t}$

a. $\mathrm{T}$ hitung $>\mathrm{t}$ tabel dan nilai signifikansi $<$ 0,05 maka variabel bebaserpengaruh signifikan

b. T hitung < t tabel dan nilai signfikansi > 0,05 maka tidak berpengaruh secara signifikan.

Dari data output SPSS Dapat dilihat bahwa : Kualitas Pelayanan(X) memperoleh nilai $\mathrm{T}_{\text {hitung }}$ sebesar $9.295>1.996$ dan nilai signifikian sebesar $0,000<0,05$, sehingga dapat diambil kesimpulan bahwa Kualitas Pelayanan (X) berpengaruh signifikan terhadap kepuasan nasabah (Y)

\section{KESIMPULAN}

Bersadarkan hasil penelitian dan pembahasan mengenai Analiis Pengaruh Kualitas Pelayanan Terhadap Kepuasan Nasabah PT. Jasa Raharja Medan , maka dapat diabil kesimpulan sebagai berikut :

1. Berdasarkan hasil nilai $\mathrm{R}^{2}$ sebesar 0.542, sehingga dapat disimpulkan bahwa kualitas pelayanan mempengaruhi kepuasan nasabah.

2. Berdasarkan hasil pengujian hipotesis dengan uji $\mathrm{t}$ diperoleh bahwa nilai $t_{\text {hitung }}>t_{\text {tabel }}(9.295>1.966)$ maka $\mathrm{H}_{\mathrm{a}}$ diterima dan $\mathrm{H}_{\mathrm{O}}$ ditolak. Jadi dapat disimpulkan bahwa kualitas pelayanan berpengaruh signifikan terhadap kepuasan nasabah. Berdasarkan signifikasi $<0,05 \quad \mathrm{H}_{\text {On }}$ ditolak, dan jika signifikasi $0,000<$ 0,05 maka $\mathrm{H}_{\mathrm{O}}$ ditolak,artinya kualitas pelayanan berpegaruh signifikan terhadap kepuasan nasabah.

3. Berdasarkan hasil linear sederhana $Y$ $=6.775+0,681 \mathrm{X}$, maka dapat disimpulkan bahwa kenaikan satu satuan kualitas pelayanan akan meningkatkan kepuasan nasabah.

\section{DAFTAR PUSTAKA}

Philip Kotler, (2010). Prinsip-prinsip Pemasaran, Erlangga. Jakarta

Philp Kotler, P. dan keller, K.L, (2009). Manajemen Pemasaran. Edsisi 12.Indeks.

Jakarta

Ramban Rupiyoadi, (2012). Kualitas Pelayana Terhadap Kepuasaan Nasabah.

Jakarta

Lovelock, (2012). Manajemen Pemasaran Jasa. Edisi 2. Jakarta.

Pujawa. (2010). KualitasPelayananJasa. Jakarta.

Peter et al. (2006). Perilaku Konsumen dan Strateg iPemasaran.Edisi keempat. Penerbit Erlangga. Jakarta.

Tjiptono. (2007). Strategi Pemasaran. Edisi Pertama. Yogyakarta.

Tjiptodan Chandra. (2007). Service Quality and Statisfaction. Yogyakarta

Waykof. (2006). Layanan Jasa. Jakarta.

Umar. (2007). Pemasaran Jasa. Penerbi tErlangga. Jakarta.

Purnama. (2010). Kepuasan Nasabah. Edisi 1.Yogyakarta.

Gilber. (2008). Pelayanan Jasa. Erlangga. Jakarta

Laksana. (2007).Pemasaran. Edisi 3. Yogyakarta

Indrianto dan Supomo. (2008). Pengukuran Variabel. Erlangga. Jakarta.

Perdinand. (2006). Pemasaran. Edisi 2. Jakarta. 